\title{
IMMUNIZATION OF CATS AGAINST MICROSPORUM CANIS
}

\author{
A. RYBNIKÁR̆ $\check{R}^{1}$, V. VRZAL ${ }^{1}$, J. CHUMELA' ${ }^{1}$ J. PETRÁŠ² \\ ${ }^{1}$ Bioveta, plc., Ivanovice na Hané \\ 2 ÚSKVBL, Brno
}

Received April 24, 1997

Accepted November 4, 1997

\begin{abstract}
Rybnikář A., V. Vrzal, J. Chumela, J. Petráš: Immunization of Cats Against Microsporum canis. Acta vet. Brno 1997, 66: 177-181.

MICANFIN, a commercial vaccine against Microsporum canis, manufactured by BIOVETA, plc., Ivanovice na Hané, was tested in a challenge bio-assay on cats. The immunized cats showed satisfactory protection against experimental infection with $M$. canis. Non-vaccinated controls given the same challenge dose developed dermatophytosis.
\end{abstract}

Microsporum canis, vaccine, protective efficacy

Skin mycotic diseases in cats have been given considerable attention for a number of years. One reason of this is, no doubt, the fact that cats are major sources of dermatophytosis in humans and particularly in children (B axter 1973, A ndriasjan 1978, Poglayen and Tam pieri 1985, Lu uder and Lunder 1992). In long-term studies Microsporum canis has been found to play the main role in the aetiology of feline skin mycosis, being incriminated in $90 \%$ to $100 \%$ of the cases examined (Pecheur and Gerin 1978, Kristensen and Krogh 1981, Sparkes et al. 1993, Larsson et al. 1994). What makes the control of the disease particularly difficult is the fact that not only evidently diseased cats, but also clinically healthy animals harbouring $M$. canis in their haircoat may be the source of infection (Moriello and De B oer 1991, Gambale et al. 1993).

For the therapy of feline dermatophytosis a number of preparations have been suggested (Moriello 1990, Moriello and DeBoer 1995). The experience with the local and oral therapy has not been invariably favourable ( De B o e r and Moriello 1995). To have a satisfactory effect, these preparations must be administered daily for a long period of time. Chemotherapeutic methods have not conferred a sufficient degree of immunity, which makes reinfection possible.

All the afore-mentioned facts and successful practical experience with immunoprophylaxis and immunotherapy of trichophytosis in farm animals ( $\mathrm{S}$ arkiso $\mathrm{V}$ and Kolesnikov 1989, Rybnikár et al. 1996b) have prompted the development of vaccines against feline dermatophytosis. Our results of testing a newly developed vaccine against $M$. canis for its protective efficacy are reported in the present report.

\section{Materials and Methods}

The experimental animals were clinically healthy 3- to 8-month old domestic cats. males and females, in a good nutritional state. The vaccine used for immunization of the cats was MICANFIN, manufactured by BIOVETA, plc., Ivanovice na Hané, Czech Republic. This liquid vaccine contains inactivated Microsporum canis culture and aluminium hydroxide as adjuvant. Nine cats were each injected subcutaneously twice with $1 \mathrm{ml}$ of the vaccine in the region behind the shoulder blade. Four cats were each injected intramuscularly twice with $1 \mathrm{ml}$ of the vaccine into the hind leg muscle. The interval between vaccination and revaccination was $1+$ days. The revaccination was carried out on the side opposite to that used for primary vaccination.

Five weeks after revaccination the immunized cats and 8 non-vaccinated controls of the same age were challenged with a virulent Microsporum canis strain. The suspension of challenge culture was inoculated into a 4 x $6 \mathrm{~cm}$ clipped and gently scarified area of the right flank at the rate of 1 to $1.5 \times 10^{6} \mathrm{CFU}$ per animal. The animals 
were then observed for clinical skin changes at the challenge site and elsewhere for 28 days after challenge. At the end of the experiment skin lesion and haircoat specimens were collected from the challenge site from all the cats for examination by culture and for microscopic examination ( $R$ y bnikár 1992 ).

\section{Results}

In 2 cats vaccinated by the subcutaneous route and in 1 cat vaccinated intramuscularly a mild swelling was observed at the site of injection; this disappeared spontaneously within one week. The remaining animals showed no undesirable post-vaccination reaction.

Table 1

Test of the protective efficacy of MICANFIN vaccine

\begin{tabular}{|l|c|c|c|c|c|c|c|}
\hline \multirow{3}{*}{ Experimental group } & \multirow{2}{*}{ Cat } & \multicolumn{7}{|c|}{ Skin mycotic changes after challenge } \\
& \multirow{2}{*}{ No. } & 10 & 15 & 17 & 21 & 25 & 28 \\
\cline { 2 - 7 } & 1 & \pm & - & - & - & - & - \\
& 2 & \pm & - & - & - & - & - \\
Cats & 3 & \pm & \pm & \pm & - & - & - \\
vaccinated & 4 & \pm & \pm & - & - & - & - \\
subcutaneously & 5 & \pm & \pm & \pm & - & - & - \\
& 6 & \pm & \pm & - & - & - & - \\
& 7 & \pm & \pm & \pm & - & - & - \\
& 8 & \pm & + & + & + & \pm & - \\
Cats & 9 & \pm & \pm & \pm & \pm & - & - \\
vaccinated & 10 & \pm & + & - & - & - & - \\
intramuscularly & 11 & \pm & + & \pm & - & - & - \\
& 12 & \pm & \pm & \pm & - & - & - \\
& 13 & + & + & + & - & - & - \\
\hline & 14 & \pm & ++ & ++ & + & \pm & \pm \\
Non-vaccinated & 15 & + & ++ & ++ & + & \pm & \pm \\
controls & 16 & \pm & \pm & + & ++ & ++ & ++ \\
& 17 & \pm & + & + & + & + & + \\
& 19 & \pm & + & + & + & + & + \\
& 20 & \pm & + & + & + & + & \pm \\
& 21 & \pm & ++ & ++ & ++ & + & + \\
& 19 & + & + & + & \pm & \pm \\
\hline
\end{tabular}

- No skin mycotic changes

\pm Minute skin changes - scales, papillae

+ Solitary mycotic foci

++ Confluent mycotic foci

The results of the protective efficacy of MICANFIN are presented in Table 1. It can be seen that the vaccinated cats responded to challenge by the development of minute superficial squamous changes which disappeared, for the most part, by day 21 (Plate XV., Fig. 1). In 2 cats vaccinated subcutaneously they persisted up to post-challenge day 21 and 25 , respectively. At the end of the experiment all the vaccinated cats were clinically negative, showing growth of new healthy haircoat. 
The non-vaccinated controls challenged with the same inoculation dose as the vaccinated animals showed either solitary or confluent mycotic foci (Fig. 2). In half of them these changes persisted till the end of the experiment. In the remaining controls they were also perceptible up to post-challenge day 28 , but showed a gradual subsidence. The results of both examination by culture and microscopic examination were in keeping with the clinical findings. They were negative in the vaccinated cats and demonstrated $M$. canis in 7 out of the 8 controls.

\section{Discussion}

The results of testing experimental vaccines against Microsporum canis have been reported by several writers. Having failed in treating a $M$. canis-affected kitten with griseofulvine, Mosher et al. (1977) used an inactivated vaccine prepared by themselves. They administered it intramuscularly once a week for a period of 5 weeks with a good therapeutic effect. The animal became clinically negative after the 5 th vaccination.

Elad and Segal (1989) developed an experimental vaccine prepared from $M$. canis ribosomal fraction and tested it on guinea-pigs by injection into the paws followed by intradermal inoculation 14 days later. In this way the humoral an cellular components of the immune system were stimulated and the vaccinated guinea-pigs became immune against experimental infection with M. canis ( $\mathrm{El}$ a d and S e gal 1994).

Inactivated vaccine was reported to induce active immunity against $M$. canis in guineapigs ( $\mathrm{Pier}$ et al. 1995). After being exposed to challenge, none of the vaccinated animals developed clinical disease, whereas $70 \%$ of non-vaccinated controls showed clinical signs of dermatophytosis.

Similar results with their own inactivated vaccine against $M$. canis were reported by Wawrzkiewicz and Ziolkowska (1996). The vaccinated guinea-pigs did not develop disease when challenged with a $M$. canis dose as high as $10^{5}$ CFU.

In our previous study ( $\mathrm{R}$ y b n i ká ř et al. 1996a) we tested the efficacy of a living vaccine against $M$. canis in dogs and calves. Its protective efficacy was good. Nevertheless, in 3 out of 5 vaccinated dogs squamous changes reminiscent of mycotic foci were observed at the inoculation site.

All the afore-mentioned experimental vaccines showed good immunogenic potency but, to our knowledge, none of them has been introduced into veterinary practice. More or less the same also applies to a vaccine prepared at the University of Wisconsin (De B o e $r$ and Moriello 1995; Moriello and De B oer 1995). The vaccine was administered to cats intradermally every other week for a period of 10 weeks. The vaccinated cats showed the same rise in their blood serum antibody titre as did the infected cats but the level of their cellular immunity was lower as against the infected animals. Protective efficacy of the vaccine against challenge and natural infection with $M$. canis was not recorded.

In 1994 Fort Dodge Laboratories introduced Fel-O-Vax MC-K vaccine into veterinary practice (Moriello and De B oer 1995). The vaccine contains an inactivated $M$. canis strain and adjuvant. It is administered subcutaneously three times in $1 \mathrm{ml}$ doses. The intervals between the vaccinations are 12 to 16 and 26 to 30 days. The safety and potency tests of the vaccine were carried out by Mori ello and De B oe r (1995). They observed a few undesirable post-vaccination reactions, namely the development of mild swelling and hair loss at the site of inoculation and post-vaccination lethargy. Therapeutic vaccination of infected cats produced an improvement of the clinical state in some but not in all the animals.

In our experiment with MICANFIN vaccine we observed slight undesirable postvaccination reaction in 2 out of 9 cats vaccinated subcutaneously and in 1 out of 4 cats after 
intramuscular administration. They consisted in mild swelling which disappeared spontaneously within a week. No further post-vaccination reactions were observed. In challenge bio-assay on cats MICANFIN showed satisfactory protective efficacy. Good protection against experimental infection with $M$. canis was recorded after both subcutaneous and intramuscular administration.

In the Czech Republic MICANFIN vaccine was introduced into veterinary practice in 1996. Up to now about 1300 cats have been vaccinated. The results evaluated so far by veterinarians and cat fanciers have been positive. The advantage of MICANFIN, compared with the afore-mentioned preparations, is that both prophylactic and therapeutic effect is achieved after its two administrations.

The results of testing MICANFIN in dogs is the subject of another report.

\section{Imunizace koček proti Microsporum canis}

Vakcína proti Microsporum canis, vyráběná v Biovetě, a.s., Ivanovice na Hané pod komerčním označením MICANFIN byla testována $\mathrm{v}$ čelenžním biologickém pokusu na kočkách. Imunizovaná zviřata prokázala vyhovující chráněnost proti experimentální infekci kulturou Microsporum canis. Nevakcinované kontrolní kočky po aplikaci stejné čelenžní dávky onemocněly dermatofytózou.

\section{References}

ANDRIASJAN, S. G. 1978: Epidemiologičeskie osobennosti mikrosporii, vyzyvaemoj Microsporum canis. Žurnal Mikrobiol. Epidemiol. Immunobiol. (10): 14 - 20

BAXTER, M. 1973: Ringworm due to Microsporum canis in cats and dogs in New Zealand. New Zealand Vet. J. 21: 33 - 37

DEBOER. D. J. - MORIELLO, K. A. 1995: Inability of two topical treatments to influence the course of experimentally induced dermatophytosis in cats. JAWMA 207: 52 - 57

ELAD, D. - SEGAL, E. 1989: Fungal ribosomal vaccines. II. Dermatophyte vaccine - initial studies on the antigenicity of a crude ribosomal fraction from Microsporum canis. Mycopathologia 105: 49 - 51

ELAD, D. - SEGAL, E. 1994: Immunogenicity in guinea - pigs of a crude ribosomal fraction from Microsporum canis. Vaccine 12: 134 - 138

GAMBALE, W. - LARSSON, C. E. - MORITAMI, M. M. - CORREA, B. - PAULA, C. R. - DE SOUZA FRAMIL, V. M. 1993: Dermatophytes and other fungi of the haircoat of cats without dermatophytosis in the city of Sao Paulo, Brazil. Feline Pract. 21: 29 - 33

KRISTENSEN, S. - KROGH, H. V. 1981: A study of skin diseases in dogs and cats. VII. Ringworm infection. Nord. veterinärmed. 33: 134 - 140

LARSSON, C. E. - NAHAS, C. R. - LEDON, A. L. B. P. - GAMBALE, W. - PAULA, C. R. - CORREA, B. 1994: Ringworm in domestic cats in Sao Paulo, Brazil, between 1981 - 1990. Feline Pract. 22: 11 - 14

LUNDER, M. - LUNDER, M. 1992: Is Microsporum canis infection about to become a serious dermatological problem? Dermatology 184: 87 - 89

MORIELLO, K. A. 1990: Management of dermatophyte infections in catteries and multiple - cat households. Vet. Clin. North Am. Small Anim. Pract. 20: 1457 - 1474

MORIELLO, K. A. - DEBOER, D. J. 1991: Fungal flora of the haircoat of cats with and without dermatophytosis. J. Med. Vet. Mycol. 29: 285 - 292

MORIELLO, K. A. - DEBOER, D. J. 1995: Feline dermatophytosis. Recent advances and recommendations for therapy. Vet. Clin. North Am. Small Anim. Pract. 25: 901 - 921

MOSHER, C. L. - LANGENDOEN, K. - STODDARD, P. 1977: Treatment of ringworm (Microsporum canis) with inactivated fungal vaccine. Vet. Med. Small Anim. Clin. 72: 1343 - 1345

PECHEUR, M. - GERIN, G. 1978: Les dermatomycoses chez les petit animaux. Ann. Méd. Vét. 122: 411 - 413

PIER, A. C., HODGES, A. B., LAUZE, J. M., RAISBECK, M. 1995: Experimental immunity to Microsporum canis and cross reactions with other dermatophytes of veterinary importance. J. Med. Vet. Mycol. 33: $93-97$

POGLAYEN, G. - TAMPIERI, M. P. 1985: Le dermatomicosi del gatto: recenti acquisizioni. Boll. Assoc. ital. vet. piccoli anim. 24: 232 - 237

RYBNIKÁR̉, A. 1992: Cross-immunity in calves after vaccination against trichophytosis. Acta vet. Brno 61: 189 $-194$ 
RYBNIKÁR̆, A., VRZAL, V., CHUMELA. J. 1996a: Vaccination of dogs and calves against Microsporum canis. Acta vet. Brno 65: $161-164$

RYBNIKÁŔ, A., VRZAL, V., CHUMELA. J., HEJTMÁNEK, M., WEIGL, E. 1996b: Vaccination of cattle against trichophytosis using the Czech vaccines. J. Mycol. Méd. 6: 93 - 94

SARKISOV, A. CH., KOLES.NIKOV, A. J. 1989: The main ways of the dermatomycoses eradication (in Russian). Veterinarija 12: 36 - 38

SPARKES, A. H. - GRUFFYDD-JONES. T. J. - SHAW, S. E. - WRIGHT, A. I. - STOKES, C. R. 1993: Epidemiological and diagnostic features of canine and feline dermatophytosis in the United Kingdom from 1956 to 1991. Vet. Rec. 133: 57 - 61

WAWRZKIEWICZ, K., ZIOLKOWSKA. G. 1996: Specific immunoprophylaxis in Microsporum canis infection in guinea pigs. J. Mycol. Méd. 6: 56 - 62

Address for correspondence:

RNDr. A. Rybnikáŕ

Bioveta a.s.

68323 Ivanovice na Hané

Czech Republic

Phone: (420) 507363321

Fax: (420) 507363294 
Plate XV.

Rybnikář A. et. al.: Immunization... pp. 177-181

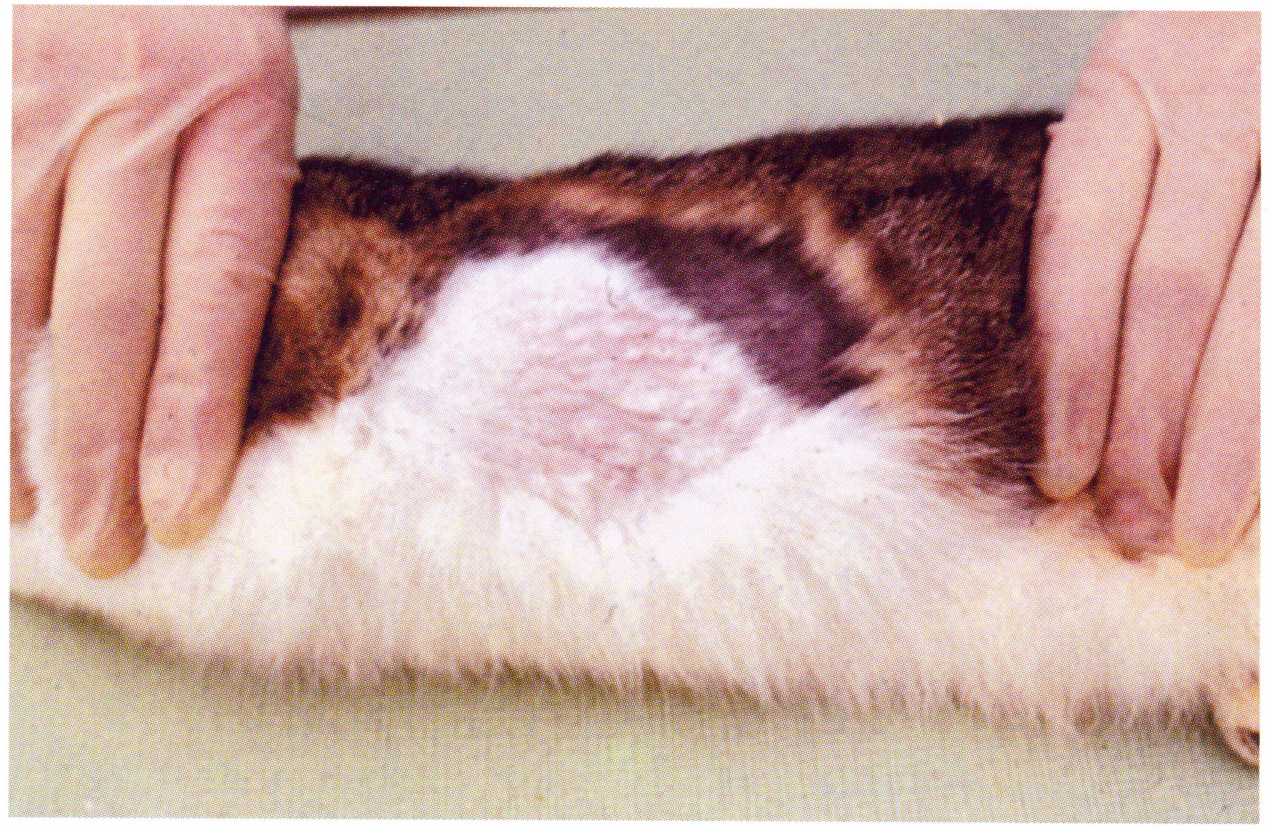

Fig. 1. Vaccinated cat No. 3. Day 21 after challenge.

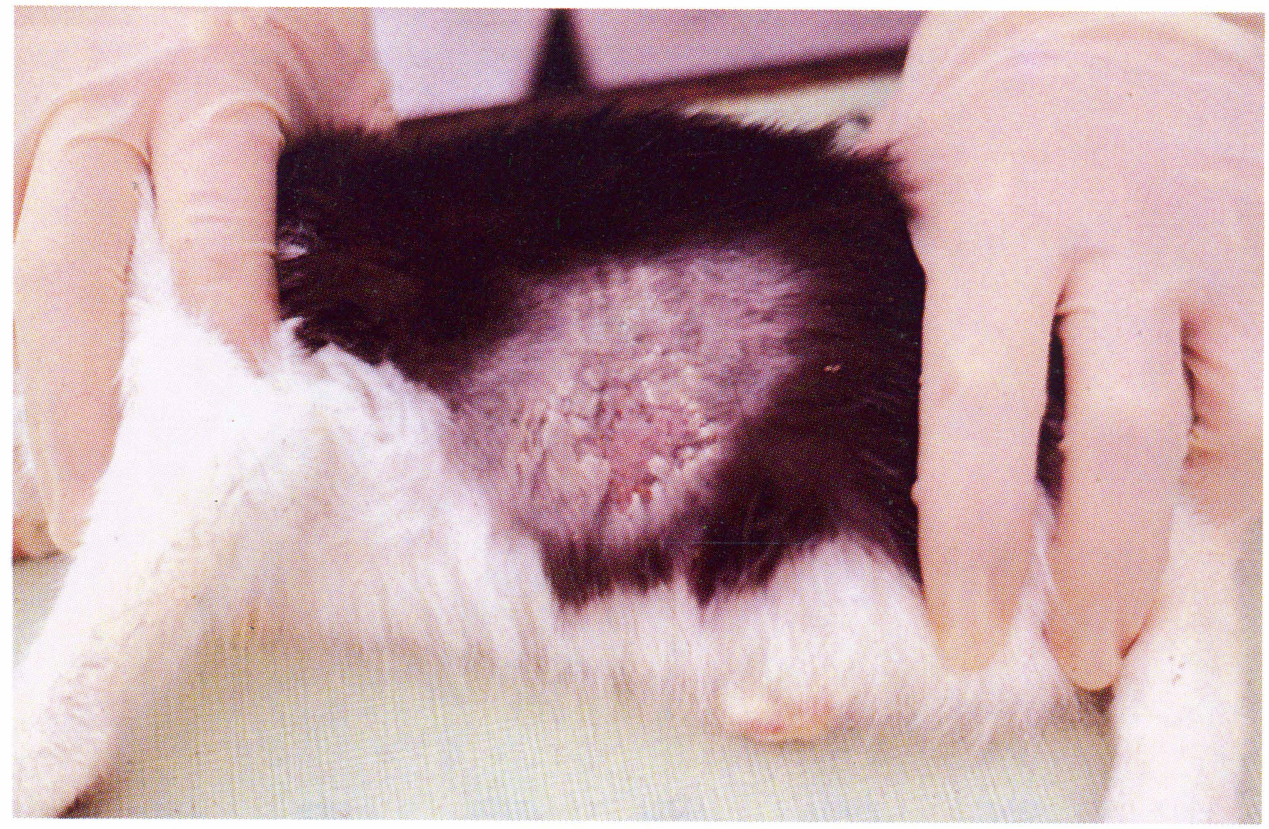

Fig. 2. Control non-vaccinated cat No. 16. Day 21 after challenge. 
Plate XVI.

Bravo C . et al.: Patency... pp. 183-188

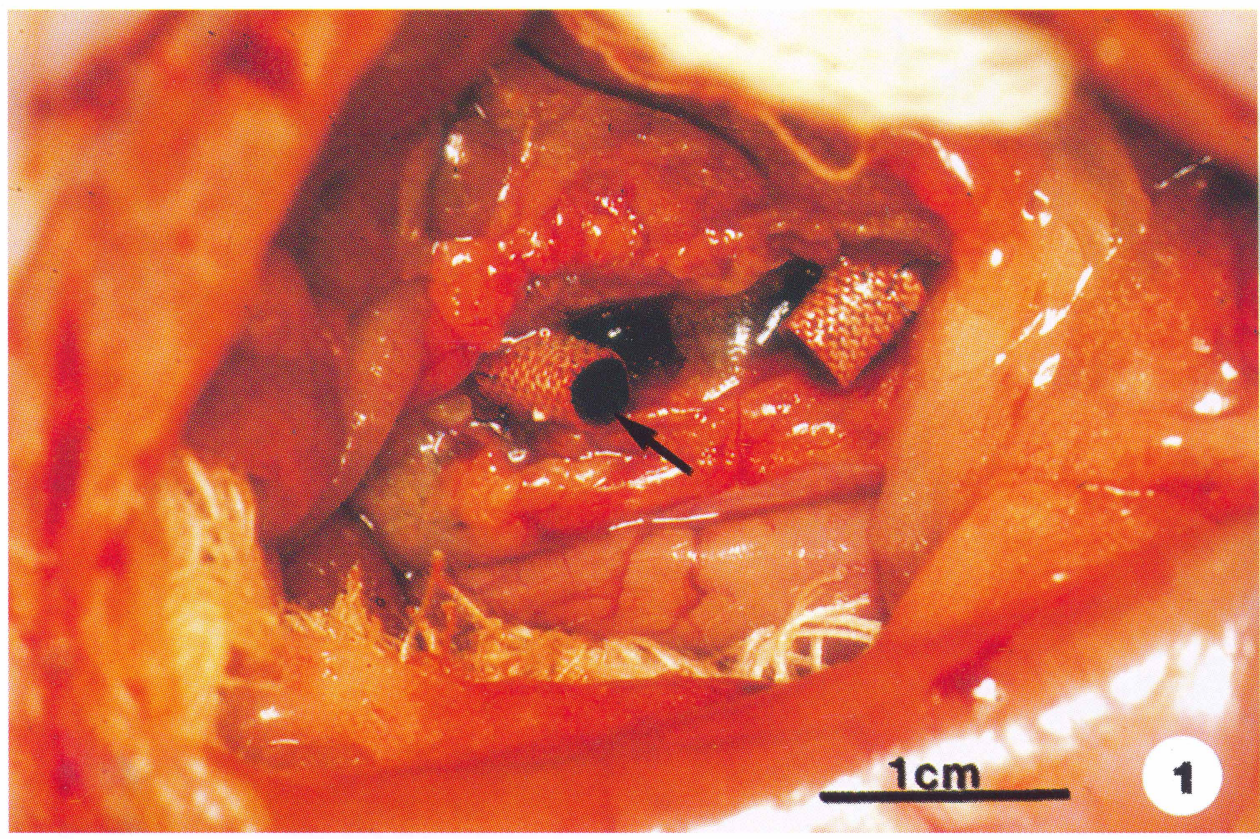

Fig. 1: Early thrombosed microprosthetic graft $(\rightarrow)$.

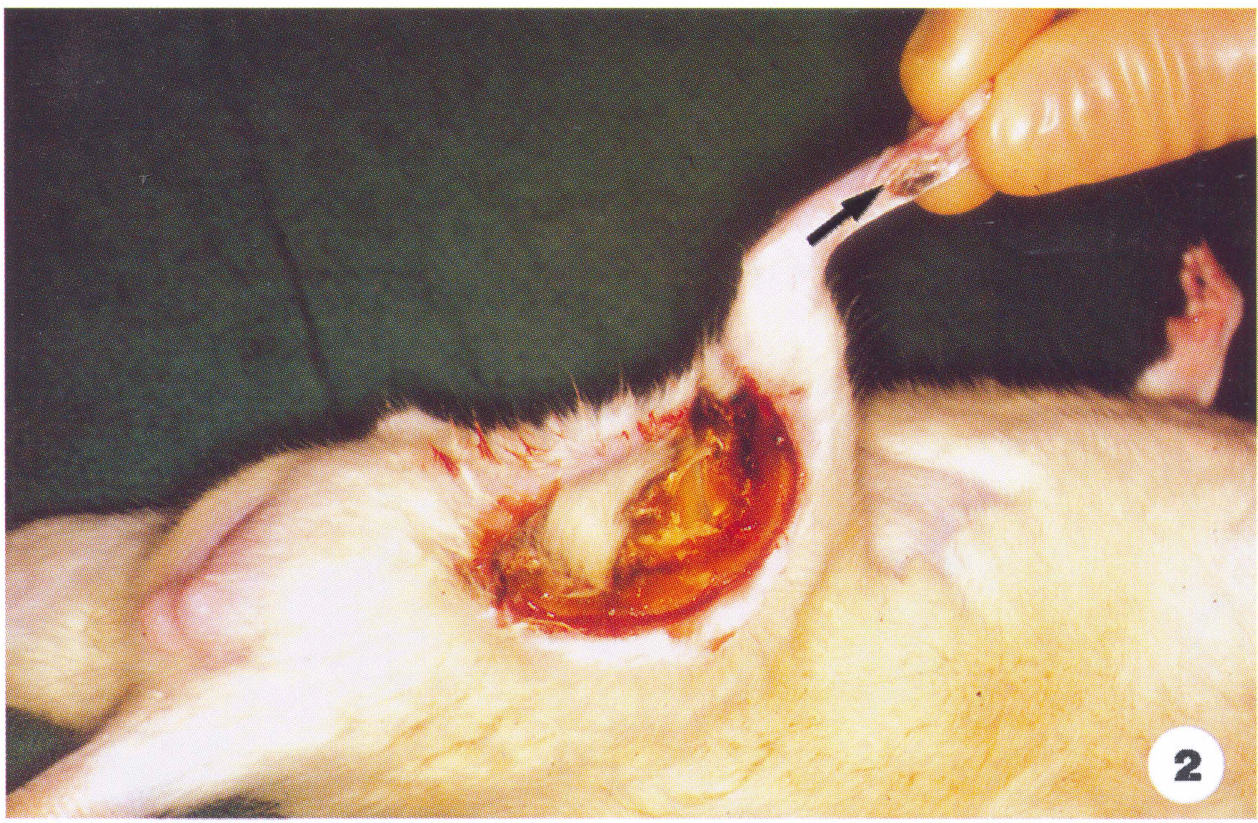

Fig. 2: Hind limb ulceration $(\rightarrow) 20$ days after ligature of the aorta. 


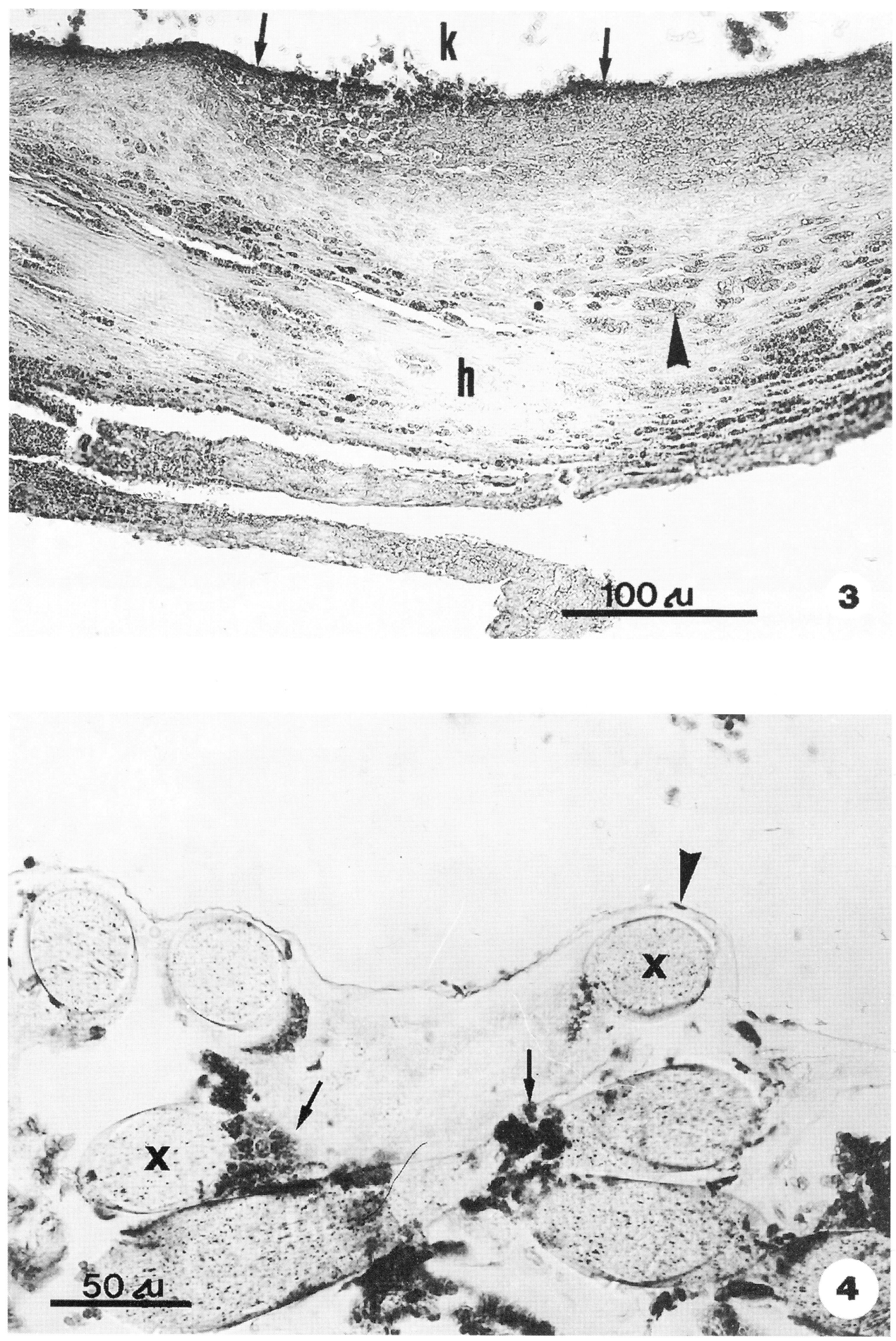




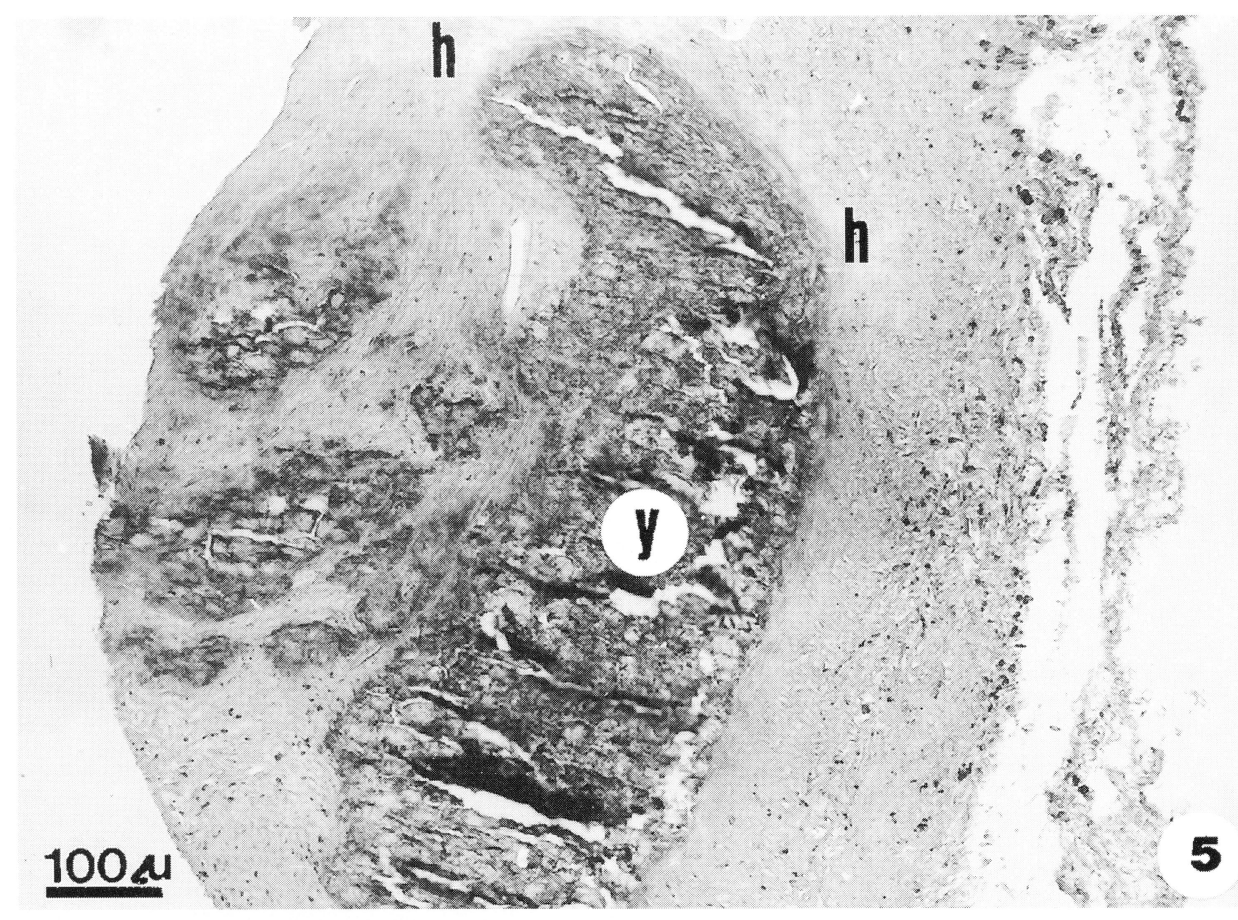

Fig. 3: The longitudinal section of the fibrous capsula of the prosthesis group 2 (32 days after implantation). Collateral channel $(\mathrm{k})$, endothelial layer $(\rightarrow)$. Hyalinized segments $(\mathrm{h})$, groups of chondroblasts like cells $(>)$. $\mathrm{HE}, \times 250$.

Fig. 4: The inner surface of the prosthesis group 2 (62 days after implantation). The wall of prosthesis (X), thrombus residues $(\rightarrow)$, the inner dark membrane with solitary fusiform cells $(\triangleright)$. HE, $\times 375$.

Fig. 5: The wall of collateral channel with mineralized segment (y) of chondroidal tissue and hyalinized areas (h), (90 days after implantation). HE, $\times 100$. 


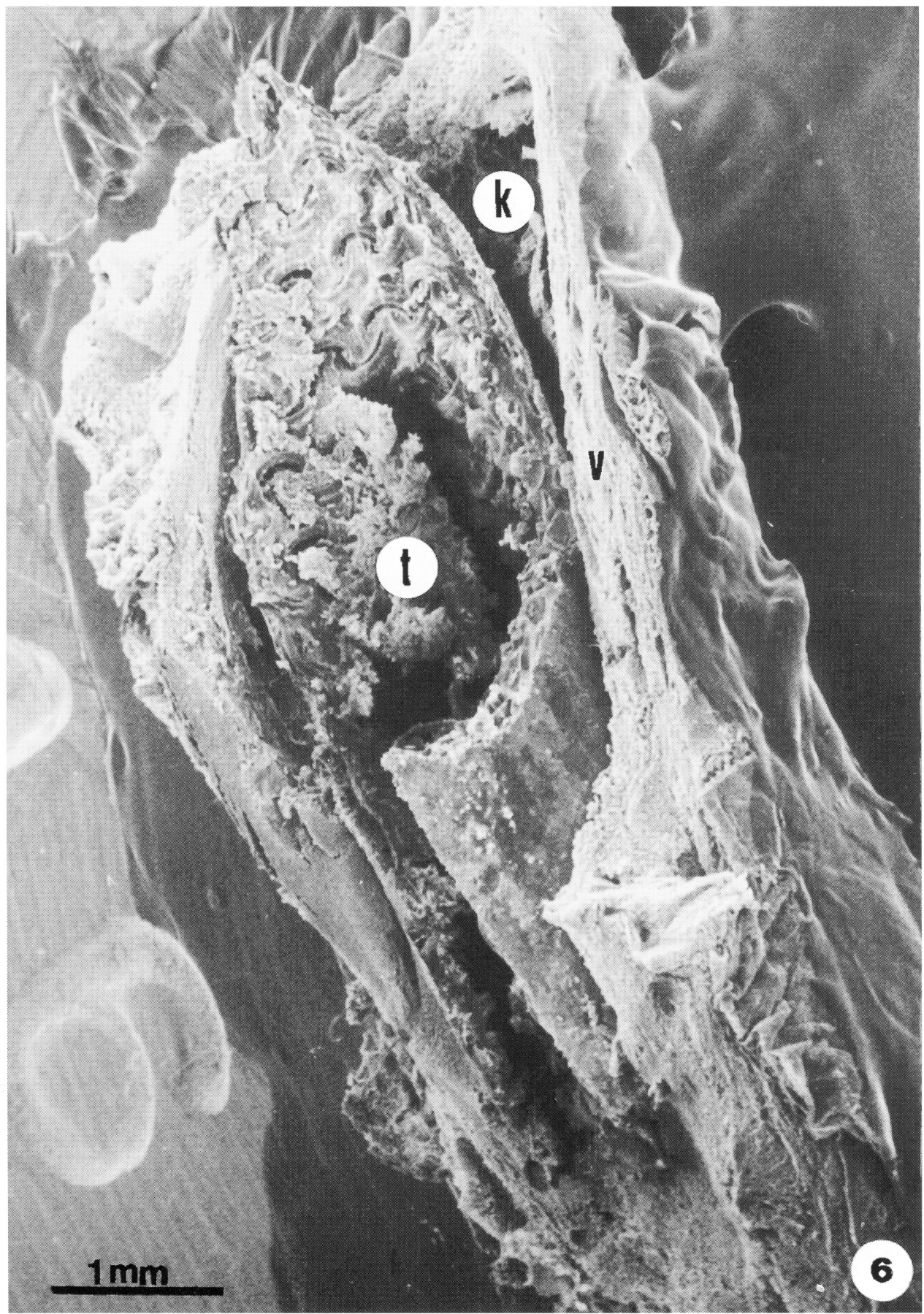

Fig. 6: Part of the prosthesis group 2 (90 days after implantation). Organized thrombus (t) on the inner surface. Fibrous capsula (v) and collateral channel (k). SEM, $\times 22$. 


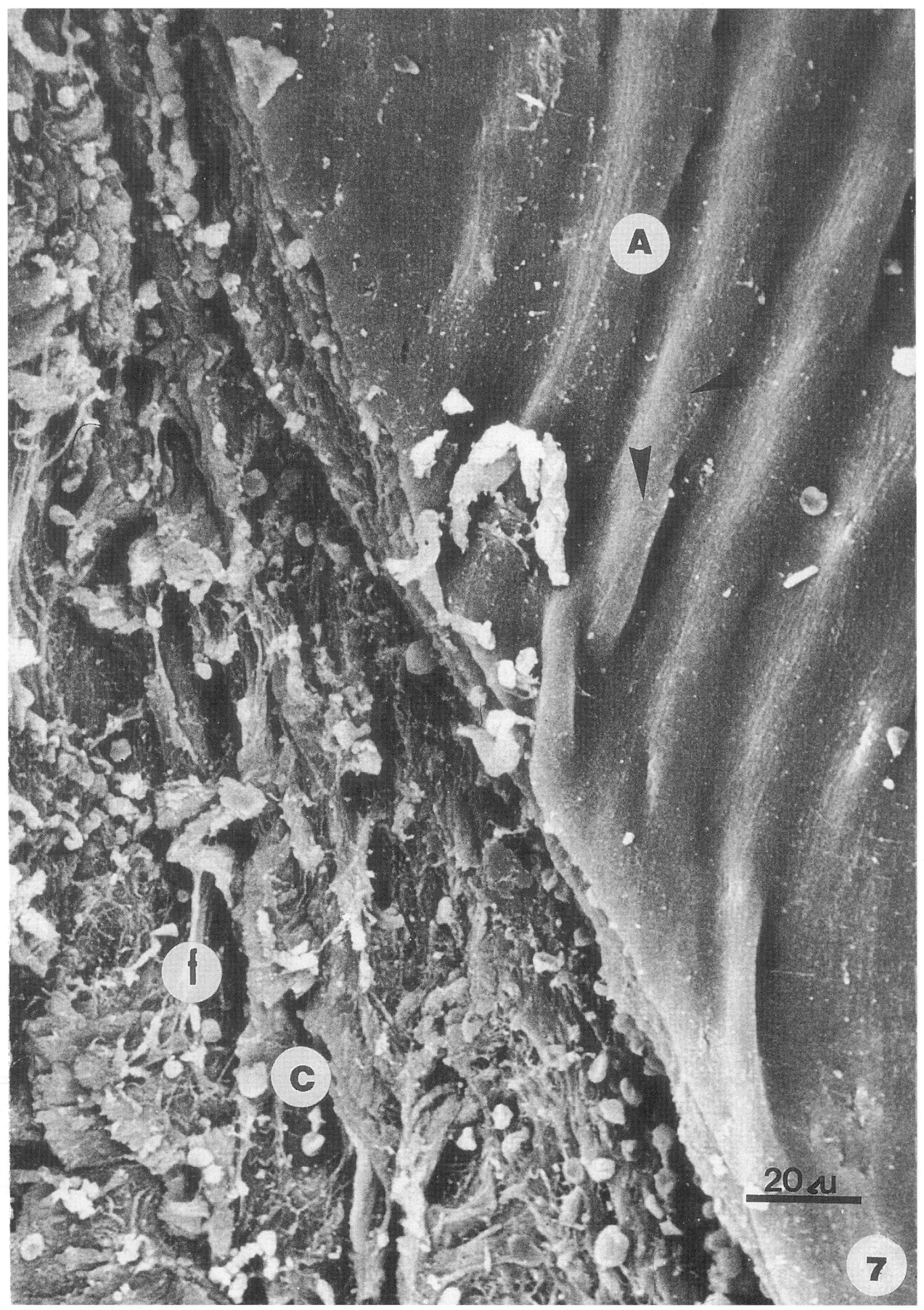

Fig. 7: Scanning electron microscopy of a cranial anastomosis with the limit between aorta (A) and prosthesis (C) group 2 (32 days after implantation). The endothelium ( $>$ ), bundles of fibrin (f), SEM, $\times 750$. 
Plate XXI.

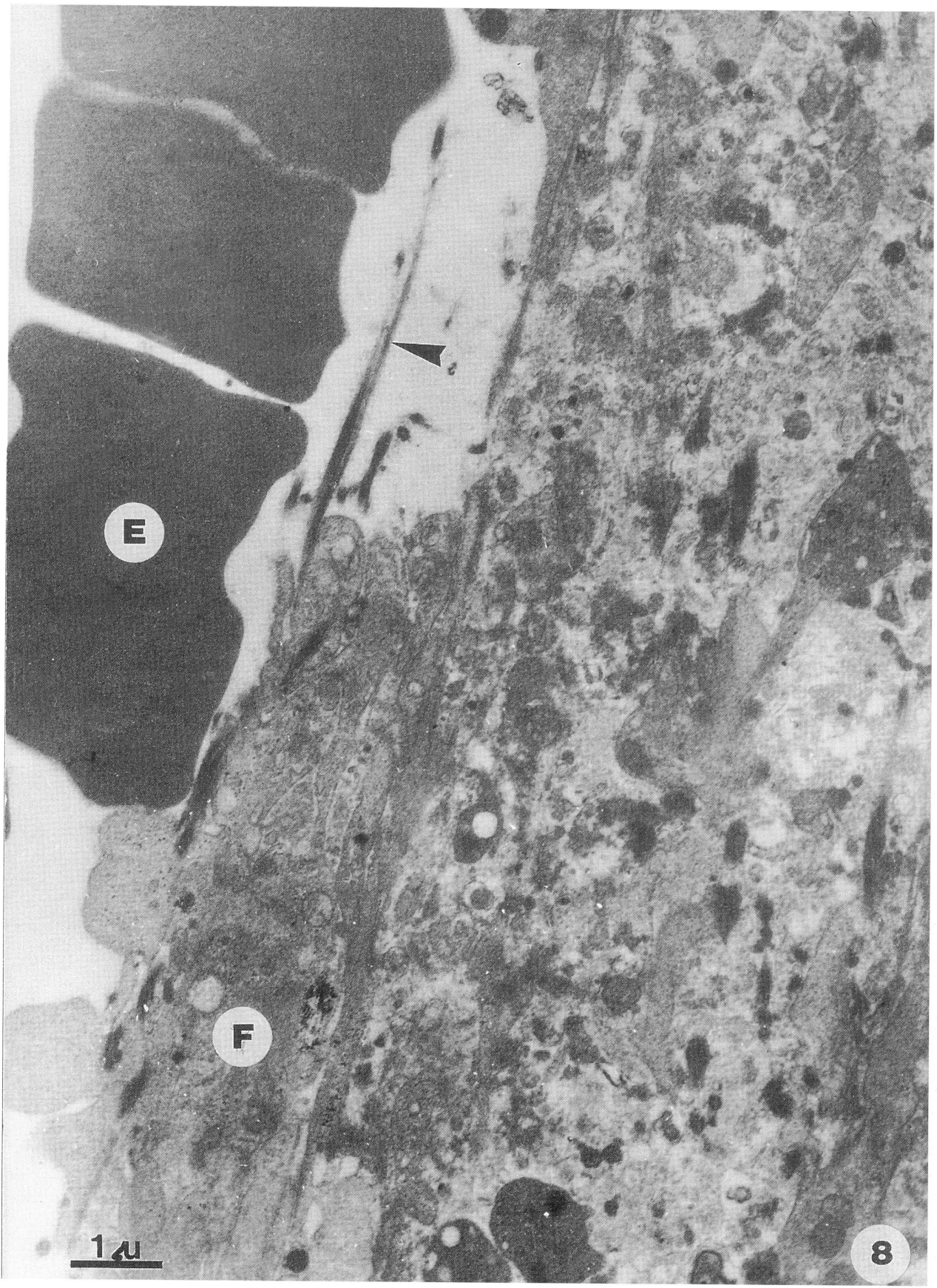

Fig. 8: Part of the inner surface of the prosthesis group 2 (7 days after implantation). Organized thrombus with bundles of fibrin ( $>$ ) and detritus. Fibroblast-like cell (F), erythrocyte (E). TEM, $\times 12000$. 


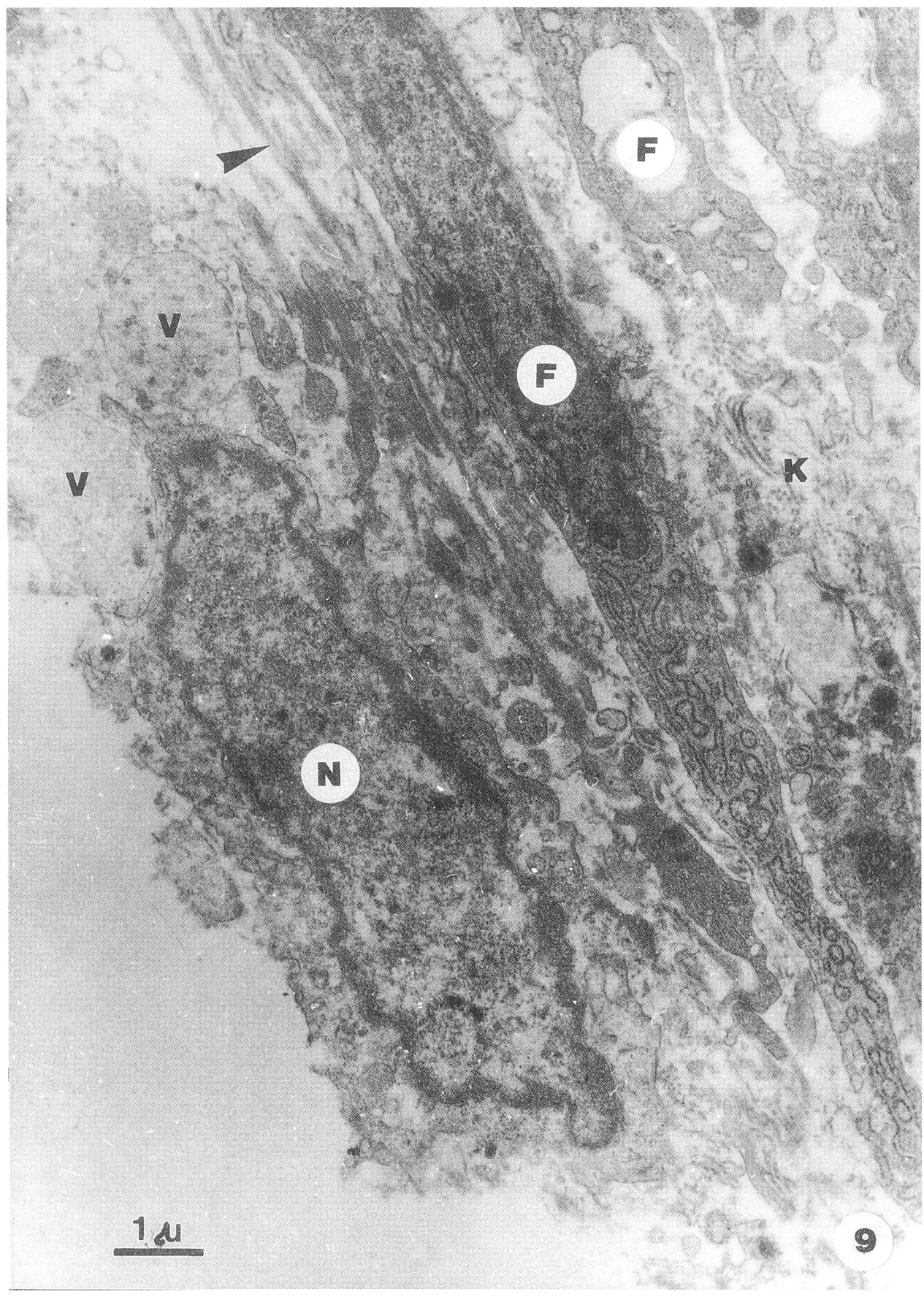

Fig. 9: The inner surface of the prosthesis group 2 (32 days after implantation). Superficial cell with nucleus (N) and numerous vacuoles $(\mathrm{V})$ in cytoplasm. Deeper layers with fibroblasts (F), bundles of collagen fibrils (K), fibrin (\). TEM, $\times 12000$. 